\title{
PHENOLIC COMPOUNDS AND FRUCTOSANS IN YACON (Polymnia sonchifolia Poepp. \& Endl.) CULTIVAR INTRODUCED IN UKRAINE, AND IN OTHER Asteraceae PLANTS AS INFLUENCED BY GROWTH CONDITIONS, VIRAL AND PHYTOPHAGE INJURY
}

\section{M.S. GINS 1 , V.K. GINS ${ }^{1}$, P.F. KONONKOV ${ }^{1}$, A.A. DUNICH ${ }^{2}$, A.V. DASHCHENKO ${ }^{3}$, L.T. MISHCHENKO ${ }^{2}$}

\begin{abstract}
${ }^{1}$ All-Russian Research Institute of Vegetable Breeding and Seed Production, Federal Agency of Scientific Organizations, 14, ul. Selektsionnaya, pos. VNIISSOK, Odintsovo Region, Moscow Province, 143080 Russia, e-mail vniissok@mail.ru, anirr@bk.ru;

${ }^{2}$ Educational and Scientific Centre «Institute of Biology», Taras Shevchenko National University of Kyiv, 64/13, Volodymyrska Str., Kyiv, 01601 Ukraine, e-mail korenevochka@mail.ru, lmishchenko@ukr.net;

${ }^{3}$ National University of Life and Environmental Sciences of Ukraine, Heroyiv Oborony str., 15, Kyiv, 03041 Ukraine, e-mail dannaval@mail.ru

Received June 3, 2015
\end{abstract}

\section{Abstract}

Antioxidants regulate functional activity and reduce the risk of development of diseases. Deficiency of antioxidants leads to sharp decrease in resistance to adverse factors. The vegetable food is the main and most available source of antioxidants for the human. Yacon (Polymnia sonchifolia Poepp. \& Endl. syn. Smallanthus sonchifolia), a new perspective plant (cv. Yudinka originated by All-Russian Research Institute of Vegetable Breeding and Seed Production), was successfully introduced in Ukraine. The content of the biologically active substances (BAS) in plants is known to be influenced by transfer from the places of natural growth in other climatic conditions, and by biotic factors, too. Despite it, only a few papers are devoted to studying of the content of phenols, oligofructans and other BAS in the yacon depending on cultivation and storage conditions, and the data on an influence of pathogens on the BAS in the yacon are absent. Therefore our aim was to determine the level of the main BAS (phenolic compounds and fructosans) in yacon of the Ukrainian introduction (in leaves and root tubers), and also to estimate the influence of biotic factors. The chromatography analysis of ethanol extracts from yacon leaves and root tubers showed the phenolic compounds among which the derivatives of hydroxycinnamic acids (HCA) prevailed. Using the high-efficiency liquid chromatography, it was shown that in the ethanol extract of dry yacon root tubers the derivatives of HCA are mainly presented by a not identified peak (X1) with keeping time of $11.45 \mathrm{~min}$, and also chlorogenic and caffeic acids were found. Main phenolic component of the fresh root tuber ethanol extracts was a substance with keeping time of 12.21 min (X2) which was absent in the dry root tubers and also was a derivative of caffeic acid. The content of chlorogenic and caffeic acids in fresh yacon root tubers was higher compared to dry ones, thus there are labile HCA derivatives changed when drying. We also studied other Asteraceae species (Echinacea purpurea, Arctium lappa, Helianthus tuberosus, Taraxacum officinale, Dahlia Cav.), and, unlike yacon, found one dominant peak of caffeic acid derivatives. It was cichoric acid in coneflower and dandelion leaves, chlorogenic acid in girasol leaves, and not identified substance (X3) coinciding in keeping time with cichoric acid in burdock leaves. In yacon leaves the accumulation of HCA derivatives was higher. Majority (not less than 18) peaks on the chromatogram had a HCA specific UF-spectrum. Three components with keeping time of 7.1-7.6 min could be identified as flavonols with regard to UF-spectra. According to direct spectrophotometry of ethanol extracts, the total amount of hydroxycinnamic acids varied from 2.8 to $4.3 \%$ (as chlorogenic acid per absolutely dry weight) depending on position of leaves on the plant. In root tubers the fructosans level changed from 36 to $45 \%$ depending on the region of cultivation and weather conditions. A comparative assay showed that in the root tubers of yacon multiplied by cutting the fructosans level was $4.98 \%$ higher than if the cutting was not used. Note, the fructosans level in the yacon root tubers was higher compared to girasol and dahlias tubers which are known as their effective sources with $6.2 \%$ and $3.03 \%$ level, respectively. A decrease in the content of main BAS in root tubers of the yacon plants influenced by biotic agents such as viruses and phytophages was also found. Particularly, in infected and damaged yacon plants the low-molecular fructosans, the sum of fructose and total fructosans, and the inulin accumulation were $8.9 \%, 13.9 \%$ and $5 \%$ lower, respectively. Thus, the data obtained by us showed that yacon is the perspective source of fructosans 

otic factors.

Keywords: yacon, phenolic compounds, fructosans, inulin, hydroxycinnamic acid, bi-

The character of food determines human health and lifespan largely. In addition to basic nutrients (proteins, fats and carbohydrates) as well as vitamins, trace elements and major mineral elements, a large group of chemical compounds with antioxidant properties is essential for humans [1]. Biologically active substances (BAS), including antioxidants regulate body functions and reduce the risk of some diseases. Deficiency of antioxidants and a breach in antioxidant protection result in a sharp decrease in the resistance to adverse factors. The vegetable food, including alternative and medicinal forms, is the main and most available source of antioxidants for humans [2].

The introduction of plants with high content of bioactive substances is actual worldwide and is associated with a lack of these compounds in the diet of the population in many countries. Estimation and selection of plants with high content of antioxidants, as well as the study of their structure are necessary for the creation of foods fortified with micronutrients and food nutrients [3]. Thus, stachys, Chinese artichoke (Stachys sieboldii Mig.), has been introduced in the Nonchernozem Zone of the Russian Federation, and the composition and content of biologically active substances and antioxidants in its nodules have been studied. In addition to sucrose, a complex of BAS and antioxidants has been found in the nodules, such as vitamin $\mathrm{C}$, phenolic compounds including flavonoids, natural glycosides [4]. This useful plant has also been introduced in Ukraine and Bulgaria [5].

Alternative sources of antioxidants include yacon, or sharp-leaved polymnia (Polymnia sonchifolia Poepp. \& Endl. syn. Smallan-thus sonchifolia), perennial plant of the Asteraceae family [6]. The main area of yacon is the middle latitudes of South America. It has already been introduced in United States, New Zealand, South Europe, Iran, Japan, Moldova, the Czech Republic, and Uzbekistan. Studies on the introduction of yacon in the CIS started at the AllRussian Research Institute of Vegetable Breeding and Seed Production (VNIISSOK) have also been continued [7-9].

Yacon is considered a valuable medicinal plant due to the high proportion of inulin, a polysaccharide which is easily absorbed in the body and serves as a substitute for sucrose in diabetics dietary, in the root tubers. Scientists from many countries have demonstrated the hypoglycemic characteristics of yacon [10-13]. Mainly, the medicinal effect of the underground part of the plant has been studied, although the leaf extracts have been shown to reduce the blood sugar level [14-17]. Due to the content of chlorogenic, caffeic acids and other phenolic compounds, its leaves also possess antioxidant properties [18-21].

The yacon Yudinka variety bred in VNIISSOK has been introduced in Ukraine [22-24]. The content of BAS may change in plants when they are transfered from the places of their natural growth in other climatic conditions. However, just a few papers deal with the study of the content of phenols, oligofructans and other BAS in yacon and of the cultivation and storage conditions for the plant.

We quantified the accumulation of the main biologically active substances in yacon variety introduced in Ukrain depending on abiotic and biotic factors (soil and climatic conditions of the region, breeding technology, pathogens and pests), and compared these data with the results of the analysis of other Asteraceae members. 
Technique. Yacon variety Yudinka (originator is the All-Russian Research Institute of Vegetable Breeding and Seed Production) and purple coneflower (Echinacea purpurea), burdock (Arctium lappa), girasol (Helianthus tuberosus), dandelion (Taraxacum officinale) and dahlia (Dahlia Cav.) were studied (research of 2011-2013, Ukraine). Yacon was grown at the experimental plot of the ESC Institute of Biology of the Taras Shevchenko National University (Kyiv) in Kyiv, Poltava, and Chernigiv regions, the rest of the samples were grown in Kyiv and Poltava regions.

Yacon was propagated by stem cuttings [27]. Stems with one pair of leaves were placed in peat pots with soil, covered with plastic caps and watered abundantly. Then they were moved into greenhouses with the air temperature of $+18 \ldots+20^{\circ} \mathrm{C}$ and illumination of 6 thousand Lx (light period duration of $16 \mathrm{~h}$ ). In the first variant of experiments on laboratory optimization of yacon reproduction and growing in the field, stem cuttings were used, the 2.5 months old yacon was planted in open ground; in the second variant yacon was not grafted, its rhizomes with regrown stems were planted in the field after 2.5 months of growth in the laboratory. Plants were dug in October (before freezing), and leaves and root tubers were collected for the study.

Liquid chromatography was performed (Agilent 1100, Agilent Technologies, USA) with a diode matrix detector and Agilent Zorbax Eclipse XDB-C18 column $(150 \times 4.6 \mathrm{~mm}$, sorbent particle size of $5 \mu \mathrm{m})$ (Agilent Technologies, USA). Gradient elution system with acetonitrile and phosphoric acid was used. Chlorogenic acid based on anhydrous matter was used as the reference substance. The presence of phenolic compounds was determined in the ethanol extract of leaves, dry and fresh whole root tubers and in their peel. Phenolic compounds in ethanol extracts of the leaves of purple coneflower, burdock, girasol, and dandelion were analyzed as well. Separated substances were identified by comparing the retention time of the peaks in the chromatograms of samples and reference compounds $(\lambda=325 \mathrm{~nm}$ was an operating wavelength).

The amount of fructosans based on dry matter and 5'-hydroxy methylfurfural were determined spectrophotometrically by standard methods at $\lambda=285 \mathrm{~nm}$ using a UV 1600 spectrophotometer (Mapada, China) [28)]. To quantify fructosan fractions, the Selivanov color reaction was used (heating fructose with hydrochloric acid to produce hydroxy methylfurfural that gives a cherry-red color with resorcinol, the intensity of which is determined by spectrophotometry) [29]. To separate high and low molecular weight fructosans, a technique based on their solubility in $96 \%$ ethanol was used. The amount of fructosans were calculated as fructose in aqueous and ethanol extracts of yacon root tubers. The results of water extraction showed the content of fructose and total fructozans, the difference between the values for the water and ethanol extracts showed the inulin content. In addition to yacon, fructosans were determined in the plants of artichoke and dahlia. The total amount of hydroxycinnamic acids (HCA) in the leaves of the $2^{\text {nd }}$ tier and the leaves of the $1^{\text {st }}$ to $4^{\text {th }}$ tiers (an average sample) were estimated by direct spectrophotometry of ethanol extracts ( $\lambda=325 \mathrm{~nm}$; UV 1600, Mapada, China) and expressed based on chlorogenic acid and dry matter [30].

The data were processed by the normal variant distribution parametric criteria, and standard deviation was calculated by the standard method using the Microsoft Excel package.

Results. Figure 1 shows yacon of different ages and the yielded root tu- 
A

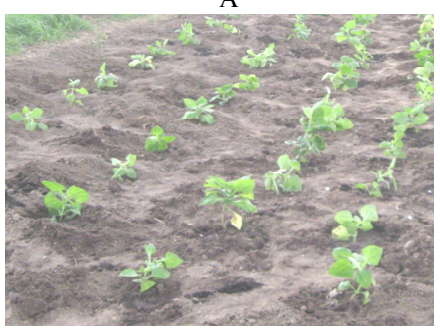

D

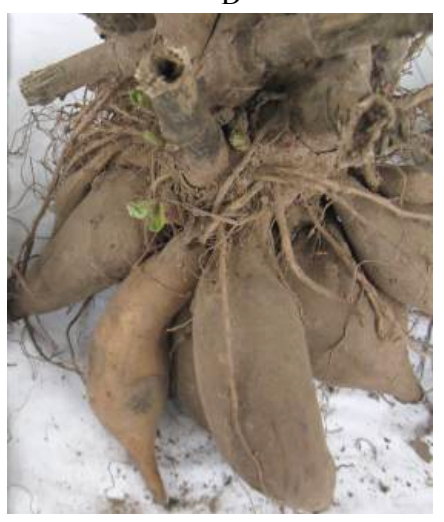

B

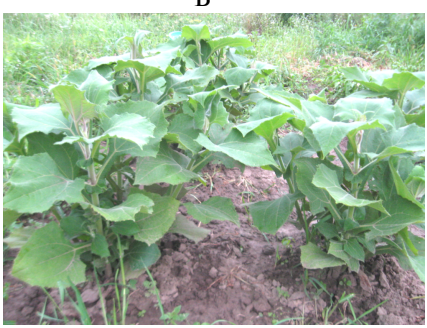

$\mathrm{C}$

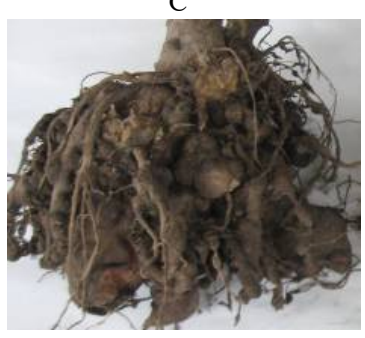

Fig. 1. Yacon (Polymnia sonchifolia Poepp. \& Endl.) variety Yudinka introduced in Ukraine: A and B - age of 2.5 and 4.5 months, respectively; $\mathrm{C}-$ affected root tubers, $\mathrm{D}-$ healthy root tubers (Kyiv Region, 2013).

The chromatography analysis of ethanol extracts from yacon leaves and root tubers showed phenolic compounds among which the hydroxycinnamic acids (HCA) derivatives prevailed. Their UV spectra had a characteristic maximum at 325$330 \mathrm{~nm}$ and a shoulder at 300-305 nm (Fig. 2, A).

In the chromatograph of the ethanol extract of dry yacon root tubers, the derivatives of HCA were presented by a main not identified peak (X1) with the retention time of $11.45 \mathrm{~min}$. Chlorogenic and caffeic acids were found as well (see Fig. 2, B).

A

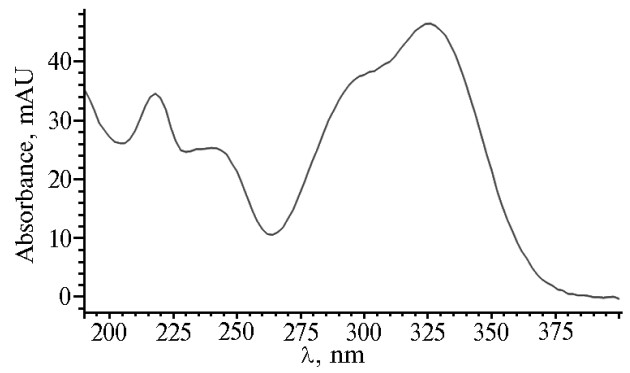

Fig. 2. UV spectrum of the peaks of the derivatives of hydroxycinnamic acids in the ethanol extracts of the leaves and root tubers (A) and the ethanol extracts chromatograms of dried (B) and fresh (C) root tubers of yacon (Polymnia sonchifolia Poepp. \& Endl.) variety Yudinka introduced in Ukraine (Kyiv Region, 2012): 1 - chlorogenic acid, 2 - caftaric acid, $\mathrm{X} 1$ and $\mathrm{X} 2$ - unidentified peaks (presumably derivatives of caffeic acid). UV 1600 spectrophotometry (Mapada, China), Agilent 1100 liquid chromatography (Agilent Technologies, USA).
B

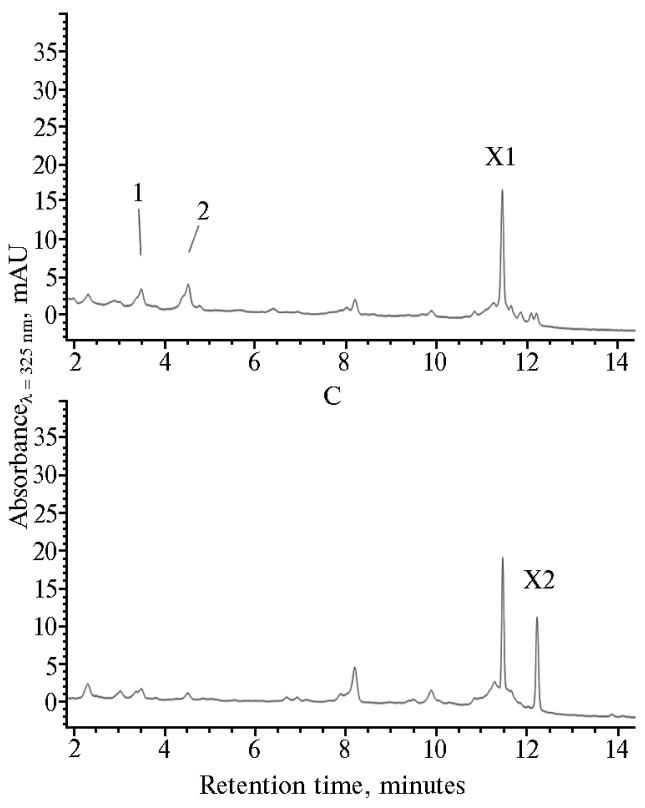

The main phenolic component of the ethanol extract of fresh root tubers was a substance with the retention time of $12.21 \mathrm{~min}$ (X2) which was not found in dried root tubers and was also a derivative of caffeic acid (see Fig. 2, C). Similar results indicating the presence of chlorogenic, caffeic and other acids, as well as quercetin and two flavonoids in yacon root tubers have been described in publications [32-35]. The analysis of chromatograms of ethanol ex- 
tracts of whole root tubers and its peel demonstrated no qualitative and quantitative differences in HCA.

In yacon leaves, the quantity of HCA derivatives was greater. Depending on the area of cultivation they contained from 2.78 to $4.30 \% \mathrm{HCA}$ which indicates the prospect of using not only root tubers but also the aerial part as medicinal raw material. The majority of peaks (not less than 18) in the chromatograms had a UV spectrum specific of HCA. Three components with retention time of 7.1-7.6 min could be identified as flavonols with regard to UF-spectra.

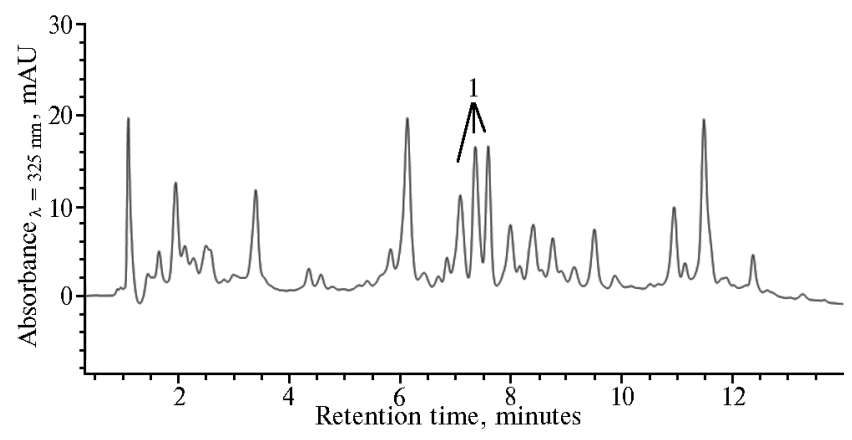

Fig. 3. Chromatogram of ethanol extract of dry leaves of yacon (Polymnia sonchifolia Poepp. \& Endl.) variety Yudinka introduced in Ukraine (Kyiv Region, 2012): 1 - flavonols. Liquid chromatography (Agilent Technologies, USA).

Our data are consistent with the results of Czech scientists who, in addition to HCA derivati-

ves, found an unknown derivative of chlorogenic acid and one unidentified flavonoid in the leaves of yacon [32].

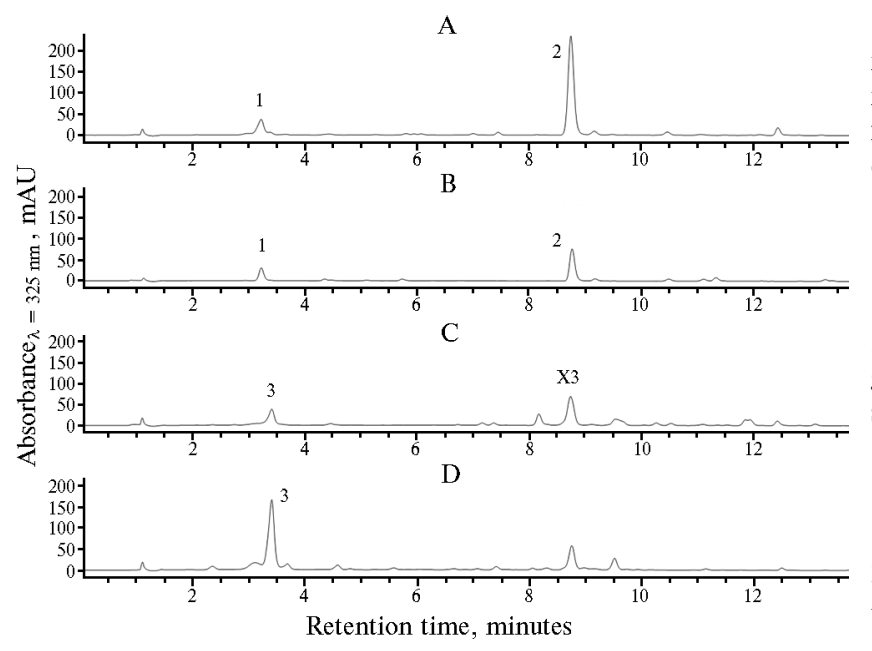

Fig. 4. Chromatograms of ethanol extracts of leaves of various representatives of the Asteraceae family (Kyiv Region, 2012): A dandelion (Taraxacum officinale), B - purple coneflower (Echinacea purpurea), C - burdock (Arctium lappa), D - girasol (Helianthus tuberosus); 1 - caftaric acid, 2 - chicory acid, 3 - chlorogenic acid, X3 - unidentified substance. Liquid chromatography (Agilent Technologies, USA).

In HCA derivatives in other plants studied, unlike yacon, a dominant peak of one of caffeic acid

derivatives was found. In coneflower and dandelion leaves it was cichoric acid, in girasol leaves it was chlorogenic acid, in burdock leaves it was an unidentified substance (X3) similar to cichoric acid in its retention time.

In yacon, in the $2^{\text {nd }}$ top tier leaves, HCA content was higher $(\mathrm{p}<0.01)$ than that of the average for the sample of the $1^{\text {st }}$ to $4^{\text {th }}$ tier. It was greater by $0.38 \%$ in Kyiv Region, and by $0.58 \%$ in Poltava Region (Table). This tendency was found in girasol, particularly, BAS level in the $2^{\text {nd }}$ tier leaves compared to the $1^{\text {st }}$ to $4^{\text {th }}$ tier was greater. These results may be due to redistribution of substances in younger leaves during the plant growth. These data will be useful in the production of high quality drugs.

Other authors demonstrated that yacon root tubers contain from 25 to $83 \%$ of carbohydrates depending on the conditions and the region [25, 36, 37]. In our study, the amount of fructosans in yacon was $44.7 \%$ in Kyiv Region, $44.0 \%$ in Chernigiv Region, and $36.1 \%$ in the Institute experimental plot (Kyiv). 
Total amount of hydroxycinnamic acids (HCA based on chlorogenic acid and absolute dry matter) in different tier leaves in yacon (Polymnia sonchifolia Poepp. \& Endl.) and other representatives of the Asteraceae family in growing regions (Ukraine, 2011)

\begin{tabular}{|c|c|c|c|}
\hline Plant species & Location & Tier & $\begin{array}{l}\text { HCA content } \\
(X \pm \sigma), \%\end{array}$ \\
\hline Yacon & Kyiv Region & $1^{\text {st }}-4^{\text {th }}$ & $3.92 \pm 0.03$ \\
\hline Yacon & Poltava Region & $1^{\text {st }}-4^{\text {th }}$ & $2.78 \pm 0.03$ \\
\hline Girasol & Kyiv Region & $1^{\text {st_-4th }}$ & $4.97 \pm 0.04$ \\
\hline Girasol & Poltava Region & $1^{\text {st }} 4^{\text {th }}$ & $5.29 \pm 0.03$ \\
\hline Yacon & Kyiv Region & $2^{\text {nd }}$ top & $4.30 \pm 0.03$ \\
\hline Yacon & Poltava Region & $2^{\text {nd }}$ top & $3.36 \pm 0.02$ \\
\hline Girasol & Kyiv Region & $2^{\text {nd }}$ top & $8.84 \pm 0.05$ \\
\hline Girasol & Poltava Region & $2^{\text {nd }}$ top & $7.47 \pm 0.04$ \\
\hline Burdock & Poltava Region & $1^{\text {st }}-4^{\text {th }}$ & $3.78 \pm 0.02$ \\
\hline Dandelion & Poltava Region & All leaves & $4.75 \pm 0.03$ \\
\hline $\begin{array}{l}\text { Not e. Please } \\
\text { «Technique». }\end{array}$ & Teter sor tox & omic spec & name to section \\
\hline
\end{tabular}

In the experiments on the optimization of yacon reproduction techniques (2013), the fructosans content in root tubers of plants grown from cuttings was $4.98 \%$ greater when compared to non-grafted plants $(56.20 \pm 0.30 \%$ versus $51.22 \pm 0.32 \%)$. Note, it was greater in yacon than in girasol $(47.51 \pm 0.31 \%)$ and dahlia $(50.68 \pm 0.28 \%)$ for which higher accumulation of these substances is typical. This means that yacon can be considered a no less promising source of fructosans.

During the yacon growing season in the field (2013), symptoms of viral diseases that affect

the number and size of the root tubers were observed (see Fig. 1, C). Leaf damage by caterpillars and the presence of other pests in the soil was found [31]. In the affected root tubers compared to healthy ones, the content of lowmolecular fructosans was lower $(40.3 \pm 0.60$ and $49.2 \pm 0.76 \%$, respectively), the level of fructose and total fructosans decreased as well $(51.10 \pm 0.77$ and $65.0 \pm 0.98 \%)$, like the amount of inulin $(10.8 \pm 0.16$ and $15.8 \pm 0.22 \%)$. This demonstrates the declining quality of medicinal plants. Similar results were obtained by us and by foreign authors for other medicinal plants [38-42].

Thus, yacon root tubers and leaves (compared to other Asteraceae memebers studied herein) can be regarded as a promising material for the production of herbal remedies and dietary supplements with antioxidant and hypoglycemic properties due to their high content of phenolic compounds and fructosans, inulin in particular. Due to a considerable reduction of the main active ingredients in yacon root tubers exposed to viral infections and pests, the methods of crop protection should be used timely.

\section{REFERENCES}

1. Gins M.S., Gins V.K. Fiziologo-biokhimicheskie osnovy introduktsii i selektsii ovoshchnykh kul'tur [Physiological and biochemical basis for vegetable crop breeding and introduction]. Moscow, 2011.

2. Carlsen M.H., H alvorsen B.L., Holte K., Bøhn S.K., Dragland S., Samp son L., Wille y C., Senoo H., Umezono Y., S a nada C., Barikmo I., B e rhe N., Walter C., Willett W.C., Phillips K.M., J a c obs D.R. Jr, B lo m hof R. The total antioxidant content of more than 3100 foods, beverages, spices, herbs and supplements used worldwide. Nutrition Journal, 2010, 9(3): 1-11 (doi: 10.1186/1475-2891-9-3).

3. Russo D., Valentão P., Andrade P.B., Fernandez E.C., Milella L. Evaluation of antioxidant, antidiabetic and anticholinesterase activities of Smallanthus sonchifolius landraces and correlation with their phytochemical profiles. Int. J. Mol. Sci., 2015, 16: 1769617718 (doi: 10.3390/ijms160817696).

4. Gins M.S., Gins V.K., K o no n k ov P.F. Ovoshchi Rossii, 2015, 23(8): 108-112.

5. Dikova B., Dashchenko A.V., T aran O.P., Glushchenko L.A., M ish he nko L.T. II Vseukraïns'ka naukovo-praktichna konferentsiya «Perspektivni napryamki naukovikh doslidzhen' likars'kikh i efiroolinikh kul'tur» [Proc. II Ukranian Conf. «Promisive areas in research of medicinal and aromatic crops»]. Berezotocha, Ukraina, 2015: 96-100.

6. Ho ng S.S., Le e S.A., H a n X.H., Le e M.H. Melampolides from the leaves of Smallanthus sonchifolius and their inhibitory activity of LPS-induced nitric oxide production. Chem. Pharm. Bull., 2008; 56(2): 199-202 (doi: 10.1248/cpb.56.199).

7. K o l e s n i k o a E.O. Biologicheskii potentsial i metody sozdaniya iskhodnogo materiala yakona (Polymnia sonchifolia Poepp. \& Endl.) pri introduktsii v TSCHR. Avtoreferat kandidatskoi dissertatsii [Biological potential of yacon (Polymnia sonchifolia Poepp. \& Endl.) and production of ini- 
tial material under introduction in Central Chernozem Russia. PhD Thesis]. Ramon', 2009.

8. S 1 e tova E.V. Introduktsiya $i$ razrabotka tekhnologii vozdelyvaniya yakona $v$ usloviyakh Nechernozem'ya v individual'nom sektore. Avtoreferat kandidatskoi dissertatsii [Yacon introduction and cultivation at private farms in Nechernozem'e region. PhD Thesis]. Moscow, 2004.

9. T o m a e v a Z.R. Biologo-khozyaistvennye osobennosti yakona $v$ usloviyakh RSO-Alaniya i perspektivy ego ispol'zovaniya. Avtoreferat kandidatskoi dissertatsii [Biological traits and economical value of yacon in Alania Republic with perspectives of its use. PhD Thesis]. Vladikavkaz, 2006.

10. Mi u r a T. Antidiabetic activity of Fuscoporia oblique and Smallanthus sonchifolius in genetically type 2 diabetic mice. Journal of Traditional Medicines (Japan), 2007, 24(2): 47-50.

11. Mishchenko L.T., Ostapchenko L.I., Khovaka V.V., Vesel'skii S.P., To r o p V.V. V sbornike: Sovremennaya farmatsevticheskaya nauka i praktika: traditsii, innovatsii, prioritety [In: Modern pharmacology and its practical use: traditions, innovations, priorities]. Samara, 2011: 76-77.

12. Mishchenko L.T., Dunich A.A., Vesel'ski i S.P., Sereda A.V. Vestnik Luganskogo natsional'nogo universiteta imeni Tarasa Shevchenko. Biologicheskie nauki, 2012, 17(252): 109-115.

13. O j a nsivu I., Fe r re ir a C.L., S a $1 \mathrm{~min}$ e n S. Yacon, a new source of prebiotic oligosaccharides with a history of safe use. Trends in Food Science \& Technology, 2011, 22: 40-46 (doi: 10.1016/j.tifs.2010.11.005).

14. Baroni S., Suzuki-Kemmelmeier F., Caparroz-Assef S.M., Cu man R.K.N., Bersani-Amado C.A. Effect of crude extracts of leaves of Smallanthus sonchifolius (yacon) on glycemia in diabetic rats. Revista Brasileira de Ciencias Farmaceuticas, 2008, 44(3): 521-530 (doi: 10.1590/S1516-93322008000300024).

15. Volp ato G.T., Vie ir a F.L., A $1 \mathrm{~m}$ e id a F.C.G., C a mara F., Le monic a I.P. Study of the hypoglycemic effects of Polymnia sonchifolia leaf extracts in rats. Abstracts of the second WOCMAP. Pt 2: Pharmacognosy, pharmacology, phytomedicine, toxicology. Wageningen (Netherlands), 1999: 319.

16. Genta S.B., Cabrera W.M., Mercado M.I., Grau A., Catalán C.A, Sán$\mathrm{ch}$ e z S.S. Hypoglycemic activity of leaf organic extracts from Smallanthus sonchifolius: Constituents of the most active fractions. Chem. Biol. Interact, 2010, 185(2): 143-152 (doi: 10.1016/j.cbi.2010.03.004).

17. Dou D.Q., Kang T.G., Qiu Y.K., Tian F. Studies on the anti-diabetic constituents of the leaves of Smallantus sonchifolius (Yacon). Planta Med., 2008, 74: 71 (doi: 10.1055/s-2008-1075267).

18. Lachman J., Fernandez E.C., Viehmannova I., Sulc M., Eepkova P. Total phenolic content of yacon (Smallanthus sonchifolius) rhizomes, leaves, and roots affected by genotype. New Zealand Journal of Crop and Horticultural Science, 2007, 35(1): 117-123 (doi: $10.1080 / 01140670709510175)$.

19. Valentova K., Moncion A., de Waziers I., Ulrichova J. The effect of Smallanthus sonchifolius leaf extracts on rat hepatic metabolism. Cell Biol. Toxicol., 2004, 20: 109120 (doi: 10.1023/B:CBTO.0000027931.88957.80).

20. Chekmarev P.A., Kononkov P.F., Gins V.K., Goryunova Yu.D. V sbornike: Rol' fiziologii i biokhimii v introduktsii i selektsii ovoshchnykh, plodovo-yagodnykh i lekarstvennykh rastenii [In: Phisiological and biochemical bases in breeding and introduction of vegetable, fruit, berry and medicinal plants]. Moscow, 2011: 350-352.

21. Lebeda A., Dolezalova I., Fernande z E., Viehmannova I. Yacon (Asteraceae: Smallanthus sonchifolia). In: Genetic resources, chromosome, engineering and crop improvement. Medicinal Plants, 2012, 6: 641-702.

22. Dunich A.A., Dashchenko A.V., Lyashuk N.I., Krys'ko I.V., Mishchenk o L.T. V sbornike: Molodezh' i nauka: modernizatsiya i innovatsionnoe razvitie strany [In: Young sientists and science: modernization and innovative development]. Penza, 2011, 1: 321-323.

23. M is h che n k o L.T., D u n i h A.A. Visnik agrarnoï nauki, 2012, 8: 45-48.

24. Mishchenko L.T., Dunich A.A., Dashchenko A.V., Lyashuk N.I., Yanishevs'ka G.S. Yakon: tekhnologiya viroshchuvannya, zbirannya ta zberigannya posadkovogo materialu (Polimnia sonchifolia Poepp. \& Endl.) /Za red. L.I. Ostapchenko Yacon (Polimnia sonchifolia Poepp. \& Endl.): technologies of growing, harvesting, and storage of planting set. L.I. Ostapchenko (ed.)]. Kiïv, 2012: 27.

25. Valentova K., Lebeda A., Dolezalova I., Jirovsky D., Simonovska B., Vovk I., Kosina P., Gasmanova N., Dzierchciarkova M., Ulrichova J. The biological and chemical variability of yacon. Journal of Agricultural and Food Chemistry, 2006, 54: 1347-1352 (doi: 10.1021/jf052645u).

26. Milella L., S a lava J., Martelli G., Greco I., Fernandez C.E., Viehmann o v a I. Genetic diversity between yacon landraces from different countries based on random amplified polymorphic DNAs. Czech Journal of Genetics and Plant Breeding, 2005, 41: 73-78.

27. Kononkov P.F., G ins V.K., Te micheva S.A., G ins M.S. Metodicheskie rekomendatsii po tekhnologi vozdelyvaniya yakona na priusadebnykh, sadovo-ogorodnykh uchastkakh i fermerskikh khozyaistvakh v usloviyakh Nechernozemnoi zony Rossii [Agrotechnologies for yacon cultivation at private farms and gardens in Nechernozem'e region of Russia: guideline]. Moscow, 2004. 
28. Mizhnarodnii kontrol' yakosti likars'kikh zasobiv «Antidiabetichnii zbir». Reestr. posvidchennya № UA/12981/01/01, vidane nakazom MOZ Ukraïni vid 21.06.13 № 533 [International quality control of medicines: antidiabetic herb collection. Certificate № UA/12981/01/01, issued by order № 533 of Ministry of Public Health of Ukraine, dated 21.06.13].

29. B elyakov K.V. Metodologicheskie podkhody $k$ opredeleniyu biologicheski aktivnykh veshchestv $v$ lekarstvennom rastitel'nom syr'e spektrofotometricheskim metodom [Spectrophotometry of bioactive compounds in plant raw material]. Moscow, 2004.

30. Ekhinatseya purpurova trava. Derzhavna Farmakopeya Ukraïni. 1-e izd., 3-e dop. [State Pharmacopoeia of Ukraine. $1^{\text {st }}$ ed., $3^{\text {d }}$ addition]. Kharkiv, 2009: 184-185.

31. Dashchenko A., Dunich A., Mishchenko L. First report about viral infection of yacon plants in Ukraine. Proc. $8^{\text {th }}$ Balkan Songress of microbiology. Veliko Tarnovo, Bulgaria, 2013: 110.

32. Vale n t ova K., U 1 ri c n o v a J. Smallanthus sonchifolius and Lepidium meyenii - prospective andrean crops for the prevention of chronic disease. Biomed. Papers, 2003, 147(2): 119-130.

33. Castro A., Caballe ro M., $\mathrm{Herb}$ as A., $\mathrm{C}$ arballo S. Antioxidants in yacon products and effect of long term storage. Ciênc. Tecnol. Aliment., Campinas, 2012, 32(3): $432-435$ (doi: 10.1590/S0101-20612012005000064).

34. Yan X., Suzuki M., Ohnishi-Kamey a ma M., Sada Y., Nakanishi T., Na$\mathrm{g}$ a t a T. Extraction and identification of antioxidants in the roots of yacon (Smallanthus sonchifolius). J. Agric. Food Chem., 1999, 47(11): 4711-4713 (doi: 10.1021/jf981305o).

35. Campos D., Betalleluz-Pallardel I., Chirinos R., Aguilar-Galvez A., Noratto G., Pedreschi R. Prebiotic effects of yacon (Smallanthus sonchifolius Poepp. \& Endl.), a source of fructooligosaccharides and phenolic compounds with antioxidant activity. Food Chemistry, 2012, 135: 1592-1599 (doi: 10.1016/j.foodchem.2012.05.088).

36. Bagautdinova R.I., Fed ose eva G.P., Tyukavin G.B., Rymar' V.P. Sel'skokhozyaistvennaya biologiya [Agricultural Biology], 2003, 1: 46-53.

37. B o st i d N.R.C. Yacon. Lost crops of the Incas: Little-known plants of the Andes with promise for worldwide cultivation. Washington, National Academy Press, 1989.

38. D unich A., Mish che nko L. Purple conefl ower viruses: species diversity and harmfulness. Biopolymers and Cell, 2015, 31(1): 15-28 (doi: 10.7124/bc.0008C8).

39. Bruni R., B i a n chi A., B ellardi M.G. Essential oil composition of Agastache anethiodora Britton (Lamiaceae) infected by Cucumber mosaic virus (CMV). Flavour Fragr. J., 2007, 22(1): 66-70 (doi: 10.1002/ffj.1760).

40. Bruni R., B e 11 ard i M.G., P a rre 11 a G., B i a n chi A. Impact of alfalfa mosaic virus subgroup I and II isolates on terpene secondary metabolism of Lavandula vera D.C., Lavandula $\times$ alardii and eight cultivars of L. hybrida. Rev. Physiol. Mol. Plant Pathol., 2006, 68(4-6): 189-197 (doi: 10.1016/j.pmpp.2006.10.004).

41. Dik ova B. Essential oil-bearing and medicinal plants - new hosts of Tomato Spotted Wilt Virus in Bulgaria. Plant Studies, 2013, III(6): 10-16.

42. Kononkov P.F., Gins M.S., Gins V.K., Sidorova N.V., Chekmarev P.A., M e l'n i k L.S. Introduktsiya yakona $v$ Rossii [Yacon introduction in Russia]. Moscow, 2011. 